\title{
Propagation of Convective Complexes Observed by TRMM in the Eastern Tropical Atlantic
}

\author{
Leonard M. Druyan* and Matthew Fulakeza
}

\author{
Center for Climate Systems Research, Columbia University and NASA/Goddard Institute for Space Studies, 2880 \\ Broadway, New York, NY 10025, USA
}

\begin{abstract}
Precipitation maxima during the West African summer monsoon propagate generally westward in tandem with African easterly waves. A heretofore unreported, repeating pattern of northward drift of precipitation maxima is detected on Tropical Rainfall Measurement Mission (TRMM satellite) time-latitude distributions of daily accumulations over the eastern tropical Atlantic. Corresponding 3-hourly TRMM accumulations show that the northward drifting envelopes of precipitation during August 2006 are often comprised of individual swaths propagating towards the southwest, presumably as mesoscale squall lines. The implied northward drift on the time-latitude distribution is a component of a resultant northwestward movement. The study examines the entire available record of TRMM precipitation observations, 1998-2010, to summarize TRMM maxima propagation over the eastern tropical Atlantic. Meridional displacements of precipitation maxima are most prevalent in June-September 2006, occurring less frequently during other summers. An investigation of geopotential and circulation fields, limited to two case studies, suggests mechanisms to explain some of the observed propagation of TRMM maxima. In one event, northward drift of the precipitation envelope is consistent with the corresponding displacement of the intertropical convergence zone trough, although the southwest propagation of individual mesoscale convection maxima does not correspond to any synoptic feature on reanalysis circulation or reanalysis downscaled by a regional model. One speculation is that southwestward propagation of precipitation maxima could be caused by regeneration of convection at outflow boundaries of mature thunderstorms.
\end{abstract}

Keywords: TRMM, African easterly waves, MCC propagation, Eastern Tropical Atlantic.

\section{INTRODUCTION}

Xue and Shukla [1] refer to diagonal swaths of atmospheric model simulated precipitation on a timelongitude Hovmöller distribution as "footprints" of African easterly wave disturbances (AEWs) moving east to west across West Africa. Druyan et al., [2] show similar diagonal swaths of TRMM observed precipitation maxima during June-September 1998, presumably also associated with westward propagating AEWs. Every summer, West Africa experiences frequent traversals of precipitation maxima, many associated with AEWs (Druyan et al., [3]).

How is the behavior of AEW-related precipitation maxima modified once the waves enter the eastern tropical Atlantic? DeLonge et al., [4] investigate the properties of a mesoscale convective system (MCS) during its transition from West Africa to the Atlantic Ocean, based on groundbased Doppler radar, radiosondes, data from an instrumented meteorological tower and rain gauges. They find that favorable thermodynamic conditions over the coast are a prerequisite to ensuring that MCSs do not dissipate at the continental-maritime transition. However, their study does not refer to TRMM observations or to the direction of MCS propagation. Futyan and Del Genio [5] do use TRMM precipitation radar data, in addition to Meteosat- 8 satellite

*Address correspondence to this author at the Center for Climate Systems Research, Columbia University and NASA/Goddard Institute for Space Studies, 2880 Broadway, New York, NY 10025, USA; Tel: 212 678-5564; Fax: 212 678-5552; E-mail: Leonard.M.Druyan@nasa.gov broadband thermal flux measurements, to differentiate between the properties of deep convective systems over West Africa and those over the neighboring (tropical) Atlantic, but they also do not discuss the movement of convective cells or clusters. Melani et al., [6] employ satellite observed IR and microwave data to describe the intraseasonal and interannual variability of West African summer monsoon rainfall characteristics, including the westward propagation of maxima, during the period JuneAugust 2004-2008. Laing et al., [7] describe and interpret propagation characteristics and diurnal cycles of organized convection over equatorial Africa based on Meteosat-7 IR brightness temperature measurements. Coherent episodes of convection result from regeneration of convection through multiple diurnal cycles while propagating westward.

Fig. (1) shows time-longitude Hovmöller distributions of TRMM precipitation during the period 10-31 August 2006 over the eastern tropical Atlantic. Fig. (1a) plots 3-hourly accumulations and Fig. (1b) plots 24-hourly accumulations, averaged over $5-15^{\circ} \mathrm{N}$ in both cases. The diagonal swaths of precipitation maxima are the footprints of westward moving AEWs, and are prominent at both time resolutions. What appears to be a single swath at daily resolution during 18-20 August, is revealed by the 3-hourly data to be 3 consecutive individual bands. On the other hand, there is only one band resolved at both resolutions during 21-23 August, and it represents precipitation associated with Tropical Storm Debbie. There are also multiple bands on 27-29 August that are resolved only by 3-hourly data. 


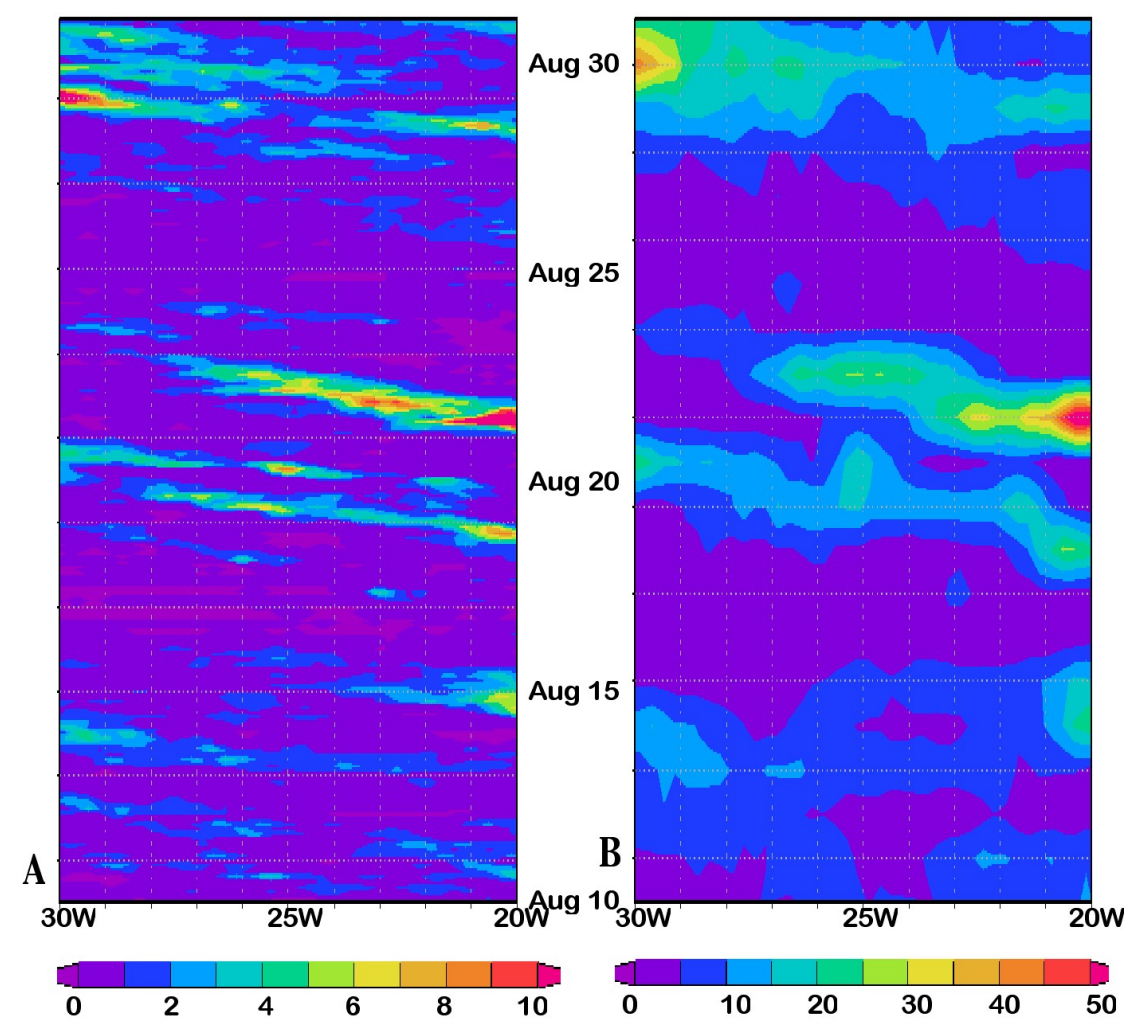

Fig. (1). Time-longitude Hovmöller distribution of TRMM precipitation (mm) averaged over 5-15N. A. 3-hourly accumulations, B. $24-$ hourly accumulations. Courtesy, NASA's Goddard Earth Sciences (GES) Data and Information Services Center (DISC).

Easterly waves traversing the eastern tropical Atlantic are also referred to as AEWs in the subsequent discussion. Based on observational data, AEWs at $700 \mathrm{mb}$ over West Africa have wave lengths ranging between $2500-4000 \mathrm{~km}$ (Burpee [8]; Reed et al., [9]). AEWs cause periodic variability in time series of recorded meridional winds $(v)$ at $850 \mathrm{mb}, 700 \mathrm{mb}$ or $600 \mathrm{mb}$ during the West African summer monsoon. Gu et al., [10] derive AEW modulated spectral properties of TRMM precipitation time series for West Africa. Other studies show that AEWs can be detected by Fourier spectral analysis of $v$ time series, which reveals spectral peaks at 3-6-day periods. Zones of maximum spectral amplitude of $v$ time series or of vorticity variance indicate trajectories of AEWs. For example, Reed et al., [11] deduce AEW trajectories based on gridded data from ECMWF analyses and forecasts projected on a $3^{\circ}$ by $3^{\circ}$ latitude-longitude grid by mapping the $700 \mathrm{mb}$ vorticity variance filtered for 2.9-4.0 and 2.9-4.7-day periods. Their analysis is confined to August-September 1985 and they show northerly and southerly AEW tracks merging into one along $19^{\circ} \mathrm{N}$ over the eastern North Atlantic Ocean. Druyan et al., [12] show the spatial distribution of spectral amplitudes of $700 \mathrm{mb}$ meridional winds $(v 7)$ for 3-6- day periods for a regional model (RM3) September 2006 simulation, which indicates two AEW trajectories, along $5^{\circ} \mathrm{N}$ at the Gulf of Guinea coast and along $15^{\circ} \mathrm{N}$ over the eastern tropical Atlantic. Thorncroft and Hodges [13] track AEW vorticity maxima at $600 \mathrm{mb}$ and $850 \mathrm{mb}$ over West Africa and the tropical Atlantic Ocean using 20 years of ECMWF analyses with an equivalent horizontal grid of $2.8^{\circ}$. They detect $\mathrm{AEW}$ trajectories along $10-13^{\circ} \mathrm{N}$, but their data refer to the entire summer. In any case, there is considerable interannual variability in AEW tracks associated with the WAM (Druyan et al., [2]; Thorncroft and Hodges [13]), but the AEW trajectories implied by mapping spectral amplitudes are all zonal. Some percentage of AEWs eventually develops into tropical storms and some into Atlantic hurricanes (Ross and Krishnamurti [14]; Hopsch et al., [15]).

The current study examines the movement of TRMM observed precipitation maxima over the summertime tropical eastern Atlantic, where they are often associated with AEWs that come from Africa.

\section{TRMM MAXIMA, AUGUST-SEPTEMBER 2006}

TRMM 3B42 V6 data are estimates of daily or 3-hourly precipitation accumulations (Huffman et al., [16]) for squares of $0.25^{\circ}$ latitude/longitude. The estimates are based on a modification of the Global Precipitation Index (GPI) from GOES geostationary satellite infrared (IR) measurements. To form the final data set, GPI values are calibrated by TRMM microwave, radar, visible and IR and rain gauge observations. Ruane and Roads [17] explain the calibration of radiances to create the 3B42 data and compare TRMM precipitation climatology to other data sets. Druyan et al., [2] compare time series of TRMM daily estimates with 34 corresponding co-located rain gauges within a $2^{\circ} \times 2^{\circ}$ area over West Africa during July-September 2000. They find a time correlation of 0.79 in the daily precipitation variability and a correlation of 0.86 between TRMM and corresponding regional climate model simulated rainfall. Good agreement between model simulated precipitation and TRMM is interpreted as evidence of mutual validation, since these are totally independent systems representing the same precipitation events. 
Fig. (2) shows the time-latitude plot of daily TRMM precipitation (averaged between $20-30{ }^{\circ} \mathrm{W}$ ) spanning August 9-September 17, 2006. A series of precipitation swaths begin between $2-6^{\circ} \mathrm{N}$ and each appears to move northward to between $13-15^{\circ} \mathrm{N}$ by about the fifth day. More information is forthcoming by examining TRMM 3-hourly accumulations. The time-latitude plot based on 3-hourly TRMM observations (Fig. 3) for August 26-September 3, 2006, shows the movement of mesoscale complexes within the swaths. At this time resolution, one can discern that, although the precipitation envelope meanders northward, individual precipitation swaths appear to be moving southward. For example, consider the four consecutive bands, respectively, during August 28-29, August 29-30, August 30-31 and September 3. On the other hand, during September 1, precipitation maxima nevertheless do appear to track northward from 9 to $14^{\circ} \mathrm{N}$. These dates are included in the National Aeronautics and Space Administration African Monsoon Multidisciplinary Analysis (NAMMA) field

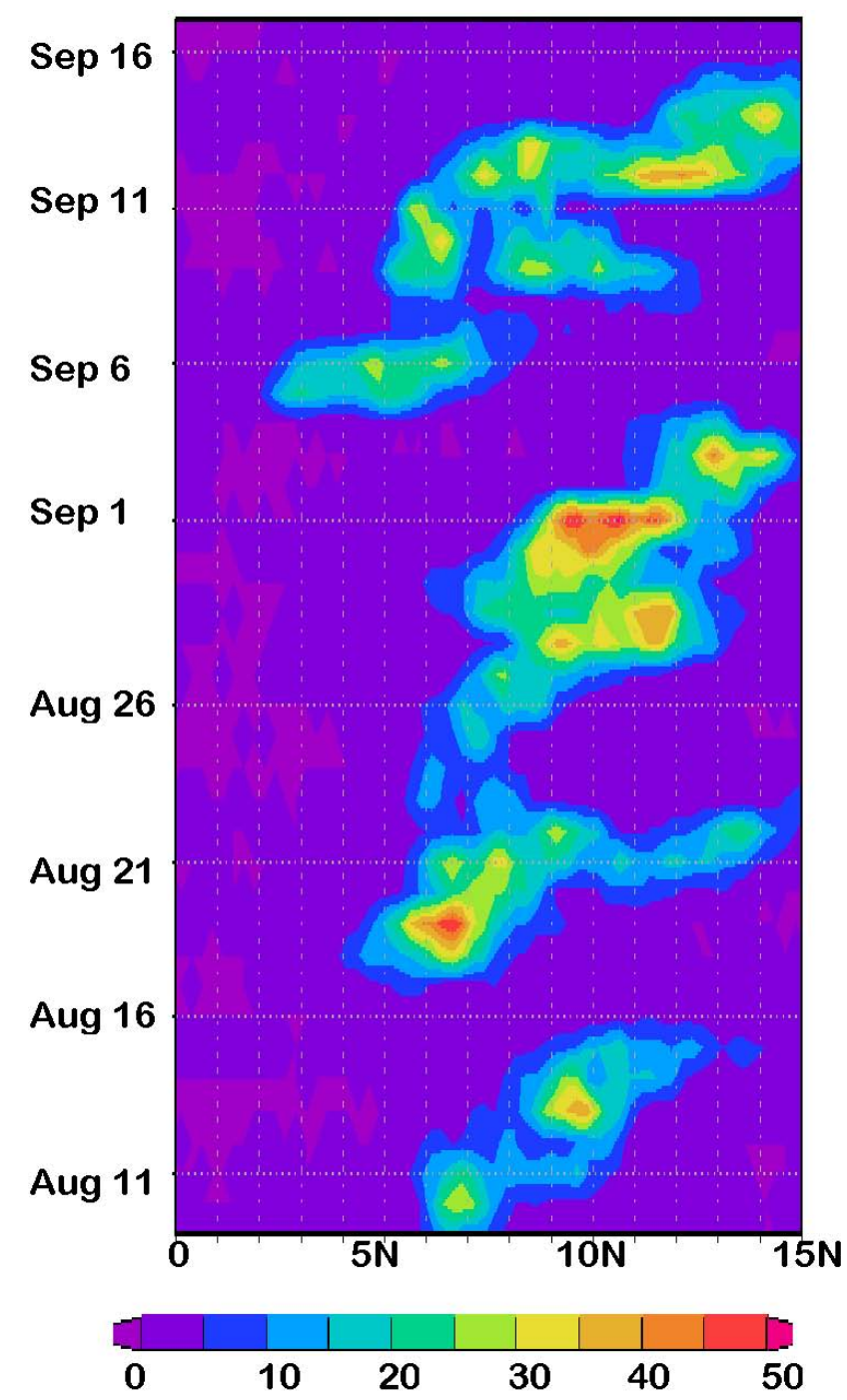

Fig. (2). Time-latitude Hovmöller distribution of TRMM daily precipitation $(\mathrm{mm})$ averaged between $20-30^{\circ} \mathrm{W}, 10$ August to 17 September 2006. Courtesy, NASA/GES/DISC. experiment, which offers a daily summary of Tropical Ocean and Global Atmosphere (TOGA) weather radar observations from Praia, Cape Verde $\left(15^{\circ} \mathrm{N}, 23.5^{\circ} \mathrm{W}\right)$. For 28 August the NAMMA TOGA blog refers to "a series of WSW-ENE oriented bands, whose motion was mainly toward the WSW...".

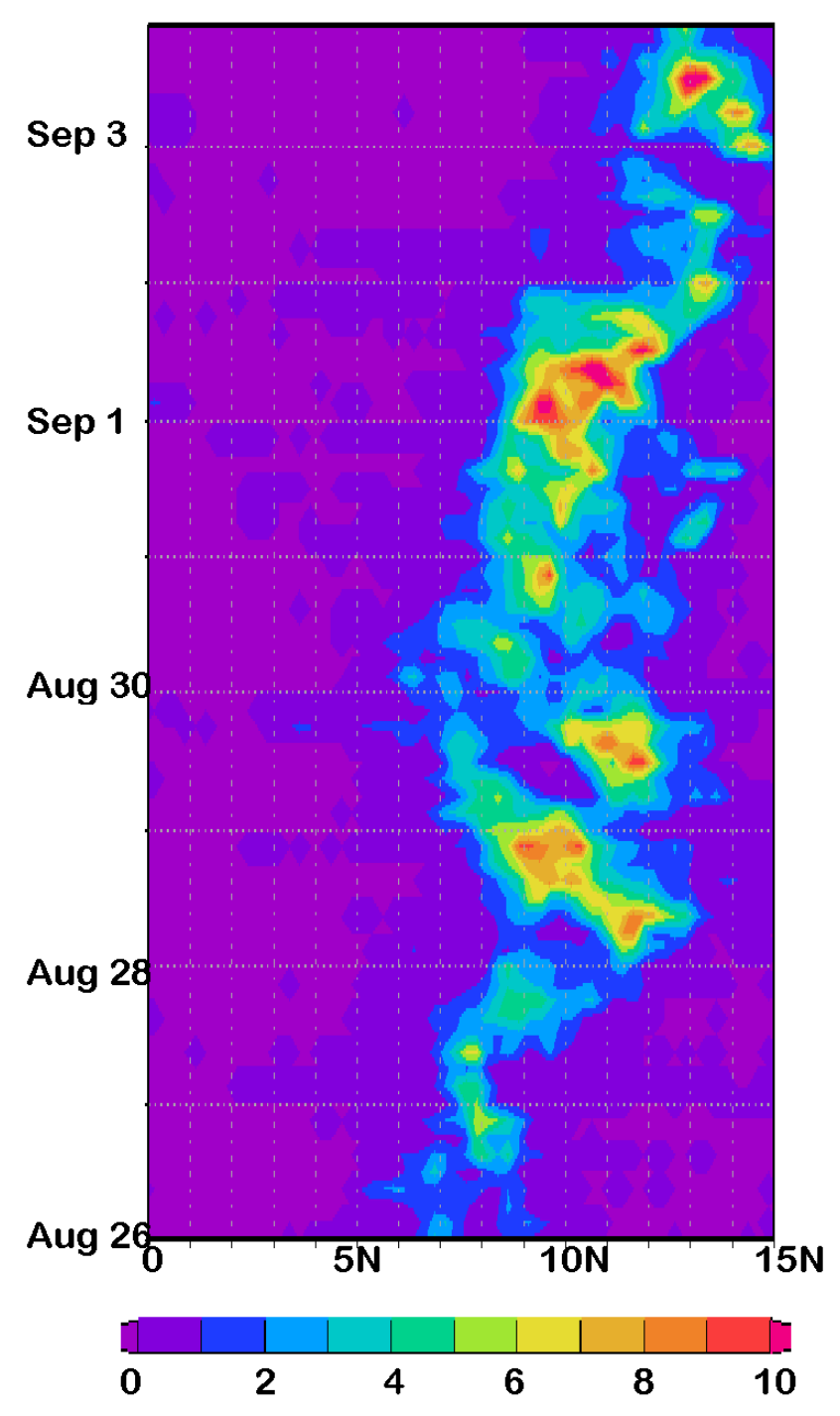

Fig. (3). Time-latitude Hovmöller distribution of TRMM 3-hourly accumulations $(\mathrm{mm})$, averaged over $20-30^{\circ} \mathrm{W}, 26$ August to 3 September 2006. Note that the color bar scale is different from Fig. (2). Courtesy, NASA/GES/DISC.

The first of the aforementioned southward moving precipitation maxima is considered in Fig. (4), which shows latitude/longitude distributions of TRMM 3-hourly rainfall accumulations spaced every six hours between 06 UTC on 28 August to 00 UTC on 29 August. A complex of heavy rainfall appears in the northeast near $12^{\circ} \mathrm{N}, 20^{\circ} \mathrm{W}$ at $06 \mathrm{UTC}$, moves southwestward and reaches $8^{\circ} \mathrm{N} 18$ hours later. The reference (triangle) is at $10^{\circ} \mathrm{N}, 25^{\circ} \mathrm{W}$.

\section{REANALYSIS}

The following discussion examines contour maps of geopotential height and circulation from the US National 

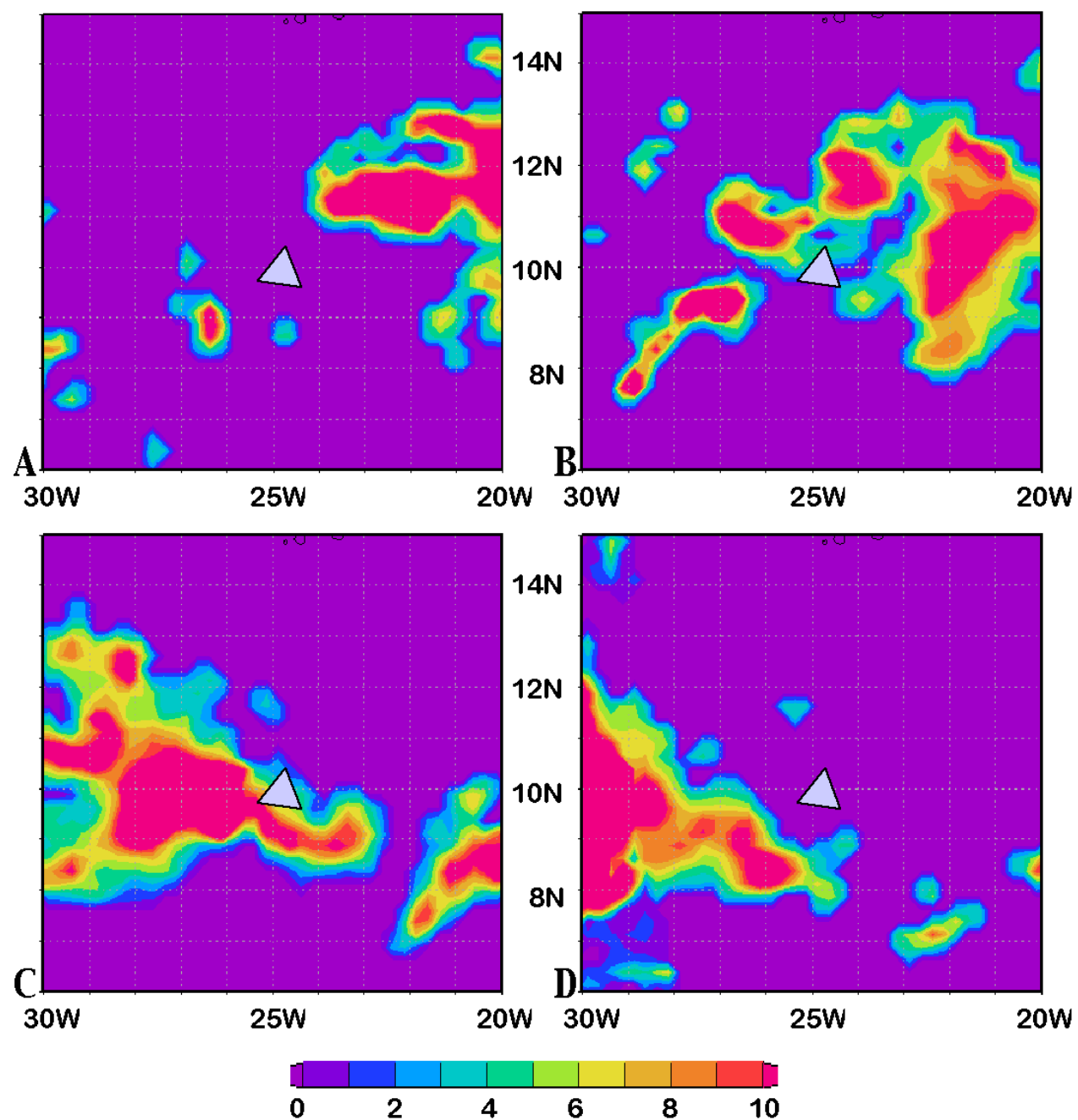

Fig. (4). Latitude-longitude distributions of TRMM 3-hour accumulations (mm) centered at A. 06 UTC 28 August, B. 12 UTC 28 August, C. 18 UTC 28 August, D. 00 UTC 29 August 2006. The reference triangle is over $10^{\circ} \mathrm{N}, 25^{\circ} \mathrm{W}$. Courtesy, NASA/GES/DISC.

Center for Environmental Prediction and Department of Energy reanalysis 2 (NCPR2) (Kanamitsu et al., [18]), in an attempt to better understand the meteorological environment for TRMM precipitation maxima discussed above. Note, however, that NCPR2 is not always representative of subsynoptic meteorological features due to its rather coarse resolution $\left(2.5^{\circ}\right.$ grid) and its model dependence over data sparse ocean regions. NCPR2 downscaled by a regional model is discussed at the end of the section.

Fig. (5) shows $925 \mathrm{mb}$ geopotential height contours for 28 August and 3 September and $700 \mathrm{mb}$ and $500 \mathrm{mb}$ height contours for 28 August. The $925 \mathrm{mb}$ low center drifts northward during this interval, from $5^{\circ} \mathrm{N}$ on 28 August to $15^{\circ} \mathrm{N}$ on 3 September. The NAMMA TOGA blog for 3 September indicates that TOGA radar detected a "longlasting mesoscale center of rotation ...centered near ... $13.35 \mathrm{~N}, 25.0 \mathrm{~W}$," which is probably associated with the geopotential low. Mid-tropospheric circulation during this period near the $25^{\circ} \mathrm{W}$ reference point (Fig. 5c, d) is southeasterly along the eastern flank of a high amplitude trough, backing from about $160^{\circ}$ on 28 August to about $100^{\circ}$ on 2 September (not shown). This circulation likely steers the near-surface low northward. This northward drift of the trough near $25^{\circ} \mathrm{W}$ probably explains the northward drift of the precipitation envelope from about $7^{\circ} \mathrm{N}$ to about $15^{\circ} \mathrm{N}$ during this interval, as seen on Fig. (3).

Why do individual convection complexes move southward on individual days (as in Figs. 3, 4), even as the envelope moves northward? Fig. $(\mathbf{6 a}, \mathbf{b})$ show NCPR2 vector winds at $10 \mathrm{~m}$, valid at 12 UTC on 28 August 2006 and 00 UTC on 29 August, respectively. Vectors are based on $10 \mathrm{~m}$ wind components gridded at $1.9^{\circ}$ spacing. In Fig. (6a), a zone of strong confluence extends from $9^{\circ} \mathrm{N}, 31^{\circ} \mathrm{W}$ northeastward towards the African coast at $12^{\circ} \mathrm{N}, 17^{\circ} \mathrm{W}$, coinciding with the heaviest precipitation, as shown in Fig. (4). This confluence line runs parallel to and slightly north of the northeast-southwest trough in $925 \mathrm{mb}$ height contours (Fig. 5a). Although the southwesterly drift of the heavy precipitation during 28 August is consistent with the northeasterly Trade Winds north of the confluence line, the NCPR2 $10 \mathrm{~m}$ wind analysis (actually 6 -h forecast) at the end of the day (Fig. 6b) does not resolve any southward displacement of the confluence line relative to its 12 UTC position. The movement of individual TRMM maxima can perhaps be better understood in a mesoscale context. Downdrafts underneath mature thunderstorms create cold 

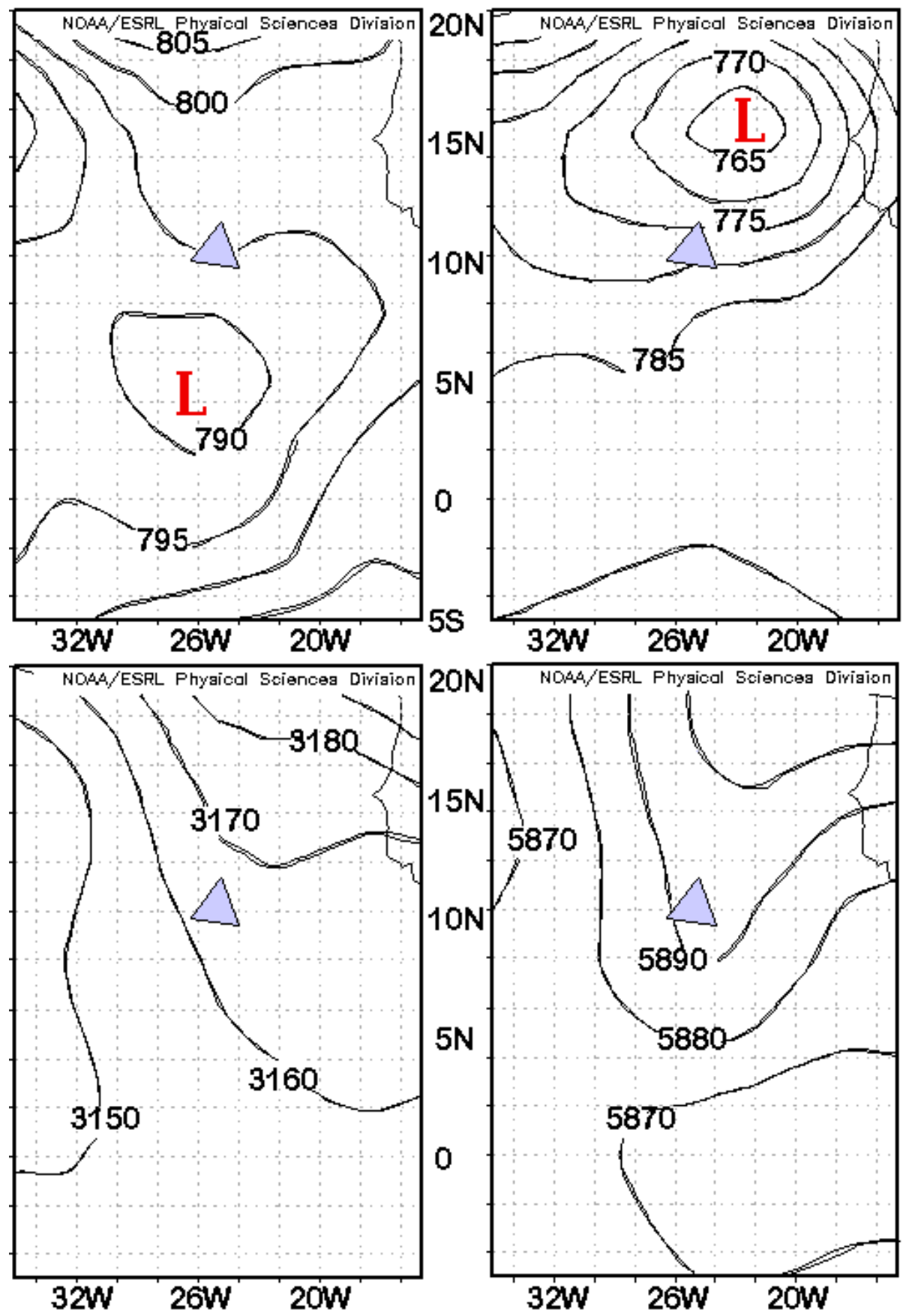

Fig. (5). Daily mean NCPR2 geopotential heights (m) of: A. the $925 \mathrm{mb}$ surface on 28 August 2006, B. the 925 mb surface on 3 September 2006. C. the $700 \mathrm{mb}$ surface on 28 August 2006; D. the $500 \mathrm{mb}$ surface on 28 August 2006. Courtesy, NOAA's Earth System Research Laboratory/Physical Sciences Division.

pools with outflow boundaries, sometimes called gust fronts, which spread out near the ground or ocean surface from the parent cell to distances of from several to tens of $\mathrm{km}$. Gust fronts are favorable areas for new convection (Weckwerth and Wakimoto [19]) and can initiate new thunderstorms that propagate in the direction of the outflow boundary (Weaver and Nelson [20]). These new cells can move in directions inconsistent with the synoptic scale circulation represented by reanalysis. Moreover, new outflows will often develop creating newer gust fronts downstream, thus propagating the resulting squall lines for hundreds of $\mathrm{km}$.
Regional model downscaling of NCPR2 to a $0.5^{\circ}$ grid is available for August 28-29, 2006 from a simulation with May 15, 2006 initial conditions. The model is the RM3, which has been previously used to study the West African monsoon (Druyan et al., [2]) and meteorology over the tropical eastern Atlantic (Druyan et al., [12]). RM3 precipitation on 28 August (not shown) over the area covered by Fig. (4) reproduces only the zonal movement detected by TRMM, but not the southward component discussed above. Moreover, changes in the RM3 downscaled NCPR 2 circulation during the second half of 28 August (Fig. 

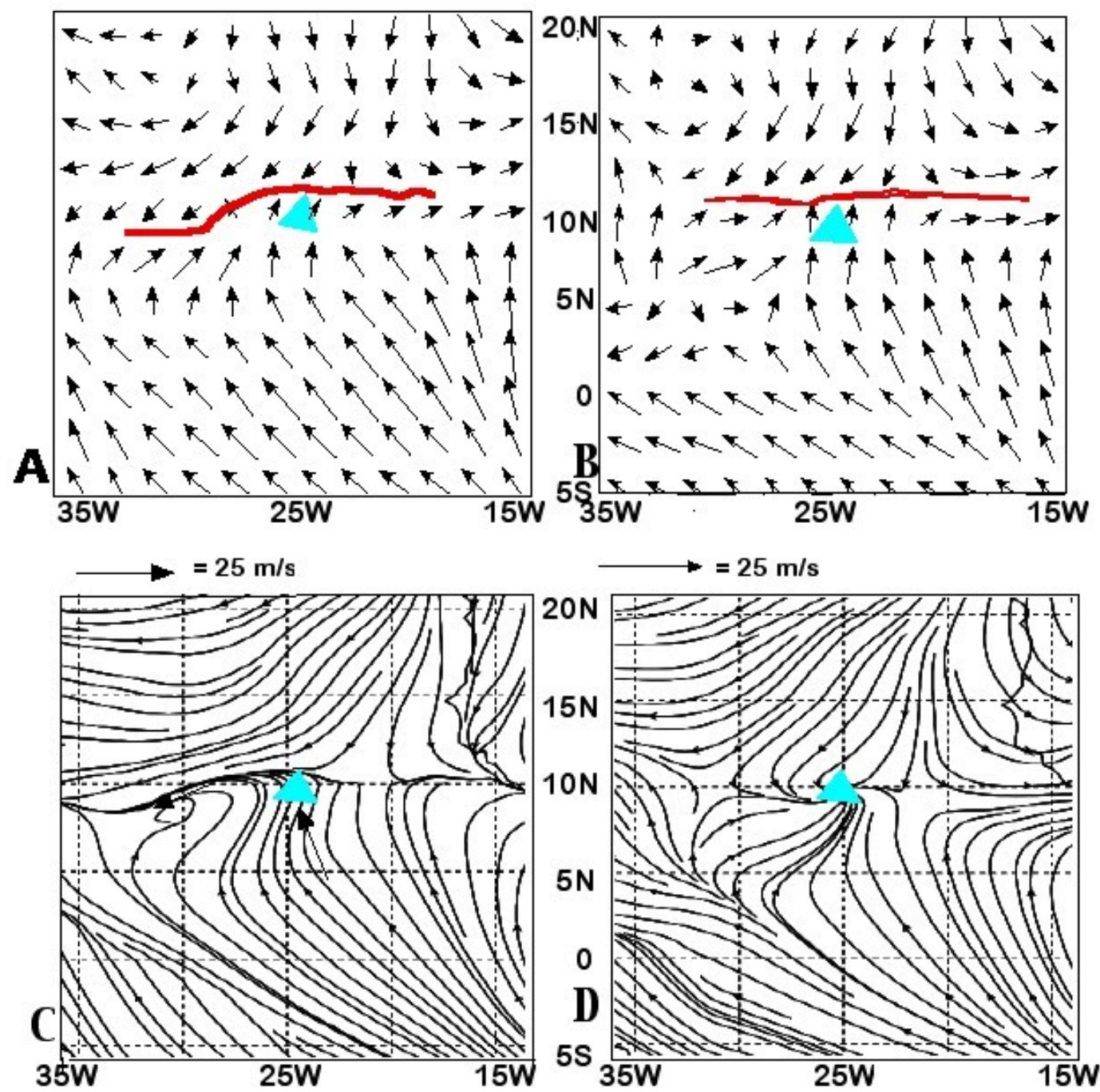

Fig. (6). NCPR2 10m vector winds, 6-hour forecast valid at, A. 12 UTC 28 August 2006 and B. 00 UTC 29 August 2006. Courtesy, NOAA/ESRL/PSD. RM3 streamlines of surface winds for, C. 12 UTC 28 August 2006 and D. 00 UTC 29 August 2006.

6c, d) do not provide explicit evidence that explains the southwestward propagation of precipitation maxima. Note that the RM3 does not parameterize storm propagation by thunderstorm outflow boundaries. The RM3 representation of surface winds, shown in Fig. (6c, d), does, however, better define the cyclonic wave near the reference point $\left(10^{\circ} \mathrm{N}\right.$, $\left.25^{\circ} \mathrm{W}\right)$. In particular, improved spatial detail provided by the downscaling highlights easterly winds along $10^{\circ} \mathrm{N}$ (at 12 UTC) that are consistent with the simulated westward propagation of precipitation maxima shown in Fig. (4).

\section{TRMM OBSERVATIONS FOR 13 SUMMERS}

Hovmöller time-latitude distributions of TRMM observations, averaged over $20-30^{\circ} \mathrm{W}$, were examined for each summer that is available from the TRMM archive, 1998-2010. Although identification is somewhat subjective, the examination showed that 2006 experienced the greatest number of northward drifting precipitation maxima, some 13 in all, between June 15-September 15. Six of the 13 summers experienced 5 or fewer northward drifting precipitation maxima, and the only other summer experiencing more than
10 was 2008. For example, Fig. (7) shows that during the first half of the summer of 2002, the only northward propagating precipitation cluster occurred between June 21 24 , and that reached only to about $9^{\circ} \mathrm{N}$. Otherwise, most precipitation events subtended about $4^{\circ}$ latitude on each day with either little apparent meridional displacement, or occasionally, north to south movement. In contrast to the deep, high amplitude troughs associated with the sequence on August 28, 2006 (Fig. 5), events with little or no northward propagation feature shallow troughs and rather zonal circulation throughout the lower and mid-troposphere. Consider the TRMM pattern over the eastern tropical Atlantic on July 9, 2002, which appears as a horizontal precipitation maximum on Fig. (7). Comparison of Fig. (8) to Fig. (5c, d) shows that the corresponding 700 and $500 \mathrm{mb}$ circulations for July 9, 2002 are more zonal with no troughing north of about $8^{\circ} \mathrm{N}$, consistent with westward steering of near-surface troughs and precipitation maxima. Contrast this with August 28, 2006, which experienced high amplitude troughs reaching to $20^{\circ} \mathrm{N}$ and ridging near the reference point at $10^{\circ} \mathrm{N}, 25^{\circ} \mathrm{W}$, producing the southeast to northwest steering. 


\section{DISCUSSION AND CONCLUSIONS}

Hovmöller time-longitude distributions of TRMM precipitation show "footprints" of AEWs, westward propagating maxima traversing West Africa and the tropical eastern Atlantic, which have been extensively discussed in the literature. The current investigation finds that increasing the time resolution from $24 \mathrm{~h}$ to 3 -hourly accumulations reveals occasional multiple swaths on some days, although they propagate westward at both time resolutions. Since AEWs are common features of the West African summer monsoon, the diagonal swaths of heavy precipitation appear every summer. This study notes a heretofore unreported pattern on the Hovmöller time-latitude distribution of TRMM precipitation over the eastern tropical Atlantic for August-September 2006. Specifically, diagonal swaths of 24 $\mathrm{h}$ accumulations indicate northward drifting precipitation maxima. Analysis based on TRMM 3-hourly accumulations during August-September 2006 additionally reveals that the northward drifting envelopes of precipitation are often comprised of individual swaths propagating towards the southwest, presumably as mesoscale squall lines. The implied northward drift on the time-latitude distribution is a component of a resultant northwestward movement.

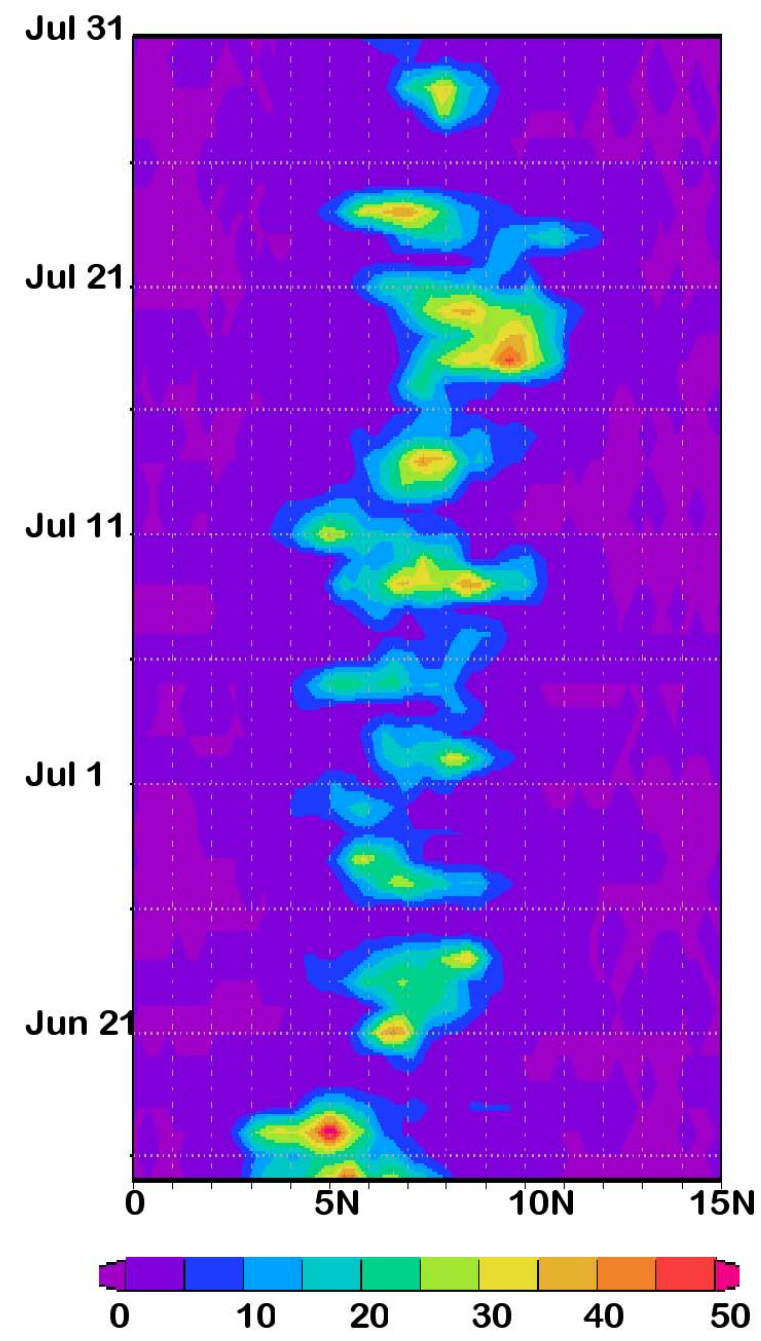

Fig. (7). Time-latitude Hovmöller distribution of TRMM daily precipitation observations $(\mathrm{mm})$ averaged between $20-30^{\circ} \mathrm{W}$ for June 15-July 31 2002. Courtesy, NASA/GES/DISC.
NCPR2 geopotential height contours are examined for August 28, 2006 and September 3, 2006, one such interval of northwestward drift of precipitation maxima with imbedded propagation of mesoscale maxima towards the southwest. Heavy precipitation in this case is associated with a confluence of $10 \mathrm{~m}$ level winds in a near-surface intertropical convergence zone trough that moves northward from $5^{\circ} \mathrm{N}$ to $15^{\circ} \mathrm{N}$. The near-surface trough, in turn, is steered by mid-tropospheric southeasterlies, east of a high amplitude $(700 \mathrm{mb})$ trough. Individual maxima of 3-hourly accumulations on August 28 propagate in the direction of the northeasterly trades, but the NCPR 2 circulation field at $1.9^{\circ}$ gridding does not resolve any movement of the confluence boundary, and neither does a higher resolution version based on downscaling with a regional model. The southwesterly propagation within $24 \mathrm{~h}$ periods could be caused by the formation and renewal of series of surface outflows and gust fronts from cold downdrafts of mature thunderstorms, but there are no field data to support this conjecture. National Aeronautics and Space Administration African Monsoon Multidisciplinary Analysis sponsored the Tropical Ocean and Global Atmosphere (TOGA) weather radar during the summer of 2006 , based in Praia, Cape Verde $\left(15^{\circ} \mathrm{N}\right.$, $23.5^{\circ} \mathrm{W}$ ). Review of the radar loop for August 28 shows only short-lived echoes within range, but they can be seen to propagate toward the southwest near $14.5^{\circ} \mathrm{N}, 24^{\circ} \mathrm{W}$. The precipitation discussed above, closer to $8-13^{\circ} \mathrm{N}$, is out of range of the radar.

Examination of TRMM data over the tropical eastern Atlantic for other summers during 1998-2010 shows that meridional displacement of precipitation maxima is not very frequent. Northward drift is detected some 13 times during June 15-September 15, 2006, but it occurs on the average only about six times per summer. During many summers, swaths on time-latitude distributions of TRMM daily precipitation are mostly horizontal, implying little meridional propagation. Mid-tropospheric geopotential height contours on one such day, July 9, 2002, are zonal over the eastern tropical Atlantic, in contrast to the high amplitude waves evident on August 28, 2006. The zonal pattern is consistent with east to west steering of both precipitation maxima and their associated near surface troughs.

The study examines the entire available record of TRMM precipitation observations, 1998-2010, from which a credible summary of TRMM maxima propagation over the eastern tropical Atlantic can be deduced. On the other hand, the investigation of geopotential and circulation fields is limited to two case studies and is therefore only suggestive of mechanisms that can explain the observed propagation of TRMM maxima.

\section{ACKNOWLEDGEMENTS}

The research was supported by National Science Foundation grant AGS- 1000874 and NASA cooperative agreement NNG04GN76A. TRMM images and data used in this study were acquired using the GES-DISC Interactive Online Visualization and Analysis Infrastructure (Giovanni) as part of the NASA's Goddard Earth Sciences (GES) Data and Information Services Center (DISC). Reanalysis 2 images are provided by the NOAA-ESRL Physical Sciences Division, Boulder Colorado from their Web site at 

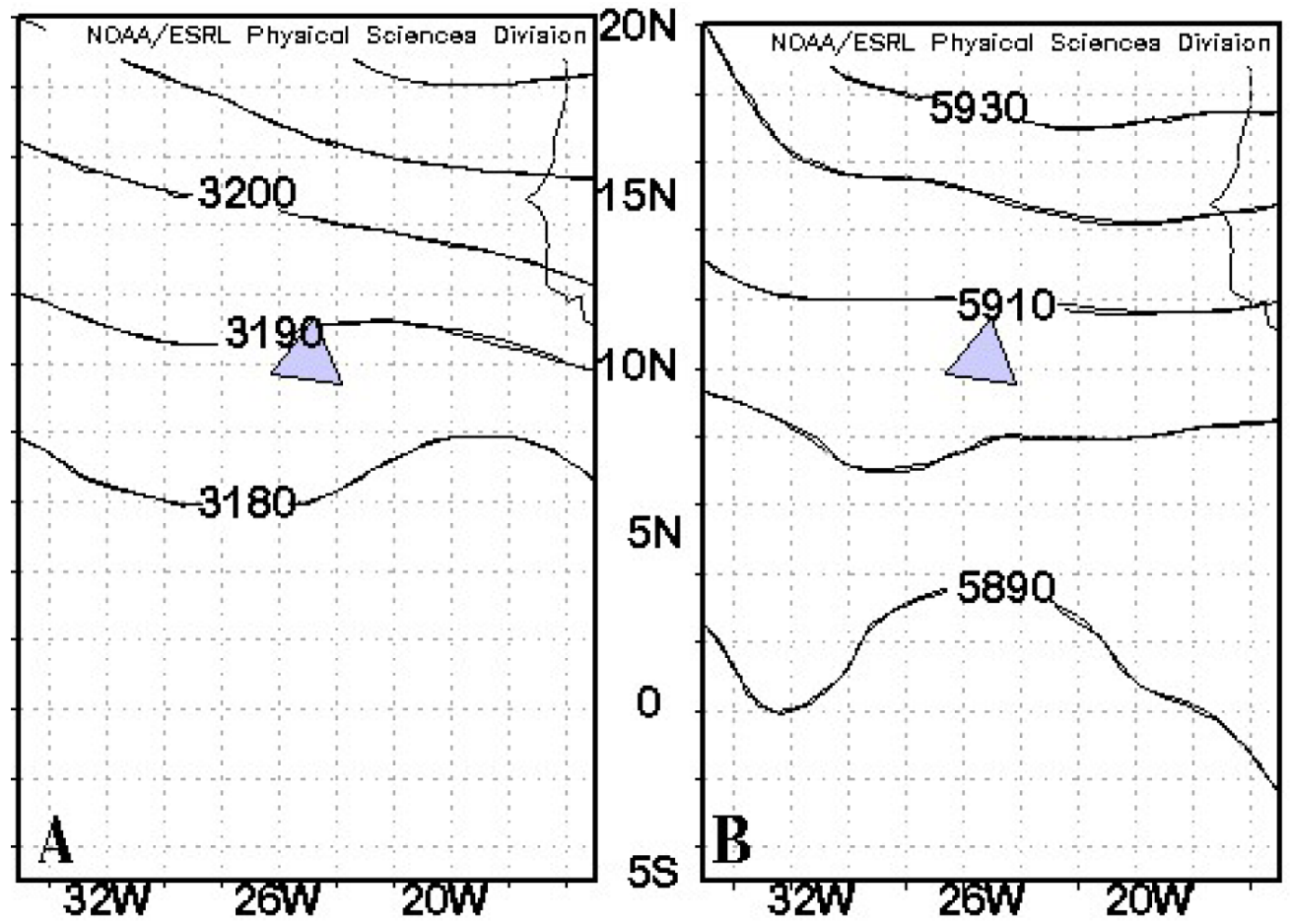

Fig. (8). NCPR2 geopotential height contours (m) on 9 July 2002 at A. 700 mb; B. 500 mb. Courtesy NOAA/ESRL/PSD.

http://www.esrl.noaa.gov/psd/. The authors gratefully acknowledge helpful suggestions from Dr. Barry Lynn and two anonymous reviewers.

\section{CONFLICT OF INTEREST}

None declared.

\section{REFERENCES}

[1] Xue Y, Shukla J. The influence of land surface properties on Sahel climate. Part I: Desertification. J Clim 1993; 6: 2232-45.

[2] Druyan L, Fulakeza M, Lonergan P. Mesoscale analyses of West African summer climate: Focus on wave disturbances. Clim Dynam 2006; 27: 459-81.

[3] Druyan L, Lonergan P, Saloum M. African wave disturbances and precipitation at Niamey during July-August 1987 and 1988. Clim Res 1996; 7: 71-83.

[4] DeLonge M, Fuentes J, Chan S, et al. Attributes of mesoscale convective systems at the land-ocean transition in Senegal during NASA African Monsoon Multidisciplinary Analyses 2006. J Geophys Res 2010; 115.

[5] Futyan J, Del Genio A. Deep convective system evolution over Africa and the tropical Atlantic. J Clim 2007; 20: 5041-60.

[6] Melani S, Pasqui M, Guarnieri F, et al. Rainfall variability associated with the summer African monsoon: A satellite study. Atmos Res 2010; 97: 601-18.

[7] Laing A, Carbone R, Levizzani V. Cycles and propagation of deep convection over equatorial Africa. Mon Weather Rev 2011; 139: 2832-53.

[8] Burpee R. The origin and structure of easterly waves in the lower troposphere of North Africa. J Atmos Sci 1972; 29: 77-90.

[9] Reed R, Norquist D, Recker E. The structure and properties of African wave disturbances as observed during Phase III of GATE. Mon Weather Rev 1977; 105: 317-33.
[10] Gu G, Adler R, Huffman G, Curtis S. Summer synoptic-scale waves over West Africa observed by TRMM. Geophys Res Lett 2003; 30: 1729.

[11] Reed R, Klinker E, Hollingsworth A. The structure and characteristics of African easterly wave disturbances as determined from the ECMWF operational analysis/forecast system. Meteorol Atm Phys 1988; 38: 22-33.

[12] Druyan L, Fulakeza M, Lonergan P, et al. Regional climate model simulation of the AMMA special observing period \#3 and the preHelene easterly wave. Meteorol Atmos Phys 2009; 103: 191-210.

[13] Thorncroft C, Hodges K. African easterly wave variability and its relationship to Atlantic tropical cyclone activity. J Clim 2001; 14: 1166-79.

[14] Ross R, Krishnamurti T. Low-level African easterly wave activity and its relation to Atlantic tropical cyclogenesis in 2001. Mon Weather Rev 2007; 135: 3950-64.

[15] Hopsch S, Thorncroft C, Tyle K. Analysis of African easterly wave structures and their role in influencing tropical cyclogenesis. Mon Weather Rev 2010; 138:1399- 419.

[16] Huffman G, Bolvin D, Nelkin E, et al. The TRMM multisatellite precipitation analysis (TMPA): quasi-global, multiyear, combinedsensor precipitation estimates at fine scales. J Hydrometeorol 2007: 8: $38-55$.

[17] Ruane A, Roads J. 6-Hour to 1-year variance of five global precipitation sets. Earth Interact 2007; 11: 1-29.

[18] Kanamitsu M, Ebisuzaki W, Woollen J, et al. NCEP-DEO AMIP-II Reanalysis (R-2). Bull Am Meteorol Soc 2002; 83: 1631-43.

[19] Weckwerth T M, Wakimoto R M. The initiation and organization of convective cells atop a cold-air outflow boundary. Mon Weather Rev 1992; 120: 2169-87.

[20] Weaver JF, Nelson SP. Multiscale aspects of thunderstorm gust fronts and their effects on subsequent storm development. Mon Weather Rev 1982; 110: 707-18. 